\title{
The syntax of interjections in isiXhosa: A a corpus-driven study
}

\author{
Alexander Andrason \\ Department of Ancient Studies | Department of African Languages, Stellenbosch University, South Africa \\ E-mail: andrason@sun.ac.za \\ Haile Matutu \\ Department of Psychology, University of Cape Town, South Africa \\ E-mail: haile.matutu@uct.ac.za
}

\begin{abstract}
This paper examines the syntactic properties of interjections in isiXhosa and their compliance with the interjectional prototype and its extra-systematicity as postulated in linguistic typology. By reviewing nearly two thousand uses of interjections in the comic genre, the authors conclude the following: in its integrity, the category of interjections is internally complex and diversified, containing members with varying degrees of canonicity and extra-systematicity. Although in various uses interjections comply with the interjectional prototype, being thus extra-systematic, in many others, their canonicity and extra-systematicity are significantly lower.
\end{abstract}

Keywords: African languages; isiXhosa; interjections; syntax; comics; extra-systematicity.

\section{Introduction}

Interjections constitute a universal word class (Ameka and Wilkins 2006: 7) and a typical feature of human language. Their relevance is particularly evident in isiXhosa (S 41) - a language that contains nearly three hundred and fifty fully grammaticalized and/or lexicalized interjectional items (Andrason and Dlali forthcoming). Although isiXhosa offers a formidable research arena, studies dedicated to interjections in this language are scarce and fragmentary. In most cases, researchers limit themselves to enumerating interjectional tokens (see Du Plessis 1978: 284-290) and presenting their meanings or functions (Jordan 1966: 204-205, Du Plessis 1978: 284-290, Oosthuisen 2016: 357). ${ }^{1}$ Sometimes, a few phonological (Oosthuisen 2016: 357) and morphological properties of interjections are identified (Oosthuisen 2016: 357-359, Kirsch, Skorge and Magona 1999: 236, Louw and Jubase 1963: 255-256, Schonstein Pinnock 1994: 196). The area that is particularly under-researched in studies on isiXhosa interjections

\footnotetext{
1 In isiXhosa scholarship, interjections (Bennie 1953: 143; Schonstein Pinnock 1994: 196; Bryant 2007; Oosthuisen 2016: 357) are often referred to as exclamations (e.g. Jordan 1966: 184; Zotwana and Wilson 1991: 264). Sometimes, both terms are simultaneously used to refer to the interjectional category (e.g. Du Plessis 1978: 284; Louw and Jubase 1963: 255). Alternatively, the label 'interjectives' is employed (Mncube 1957: vii).
} 
concerns syntax. All mentions of the syntactic properties of interjections can be reduced to a single statement: interjections "have no effect on [the] grammatical construction of a sentence" (Schonstein Pinnock 1994: 196) because they fail to enter into a relationship with, or exert effects on, its remaining components (Louw and Jubase 1963: 255; Oosthuisen 2016: 357). This statement never emerges from a process of rigorous analysis, nor is it ever substantiated by empirical evidence. ${ }^{2}$

Although, as mentioned above, interjections constitute a pervasive linguistic feature, their visibility in language is uneven. Interjections are common in oral discourses (Romero-Trillo 2006: 640; Stange and Nübling 2014: 1983; Stange 2016: 7). In contrast, their presence is much more limited in written discourse. Noticeable exceptions are the genres of written language that closely imitate spoken language - for instance, drama plays, emails, WhatsApp messages (Frehner 2008; Forster, Borgwaldt, and Neef 2012: 122; Stange and Nübling 2014: 1983; Andrason and Dlali forthcoming) and comic strips (Fernández Cuesta 1990: 551; Nübling 2004: 16; de la Cruz Cabanillas and Tejedor Martínez 2009: 56-57; Forster, Borgwaldt, and Neef 2012: 122; Stange and Nübling 2014: 1983; Bednarczyk 2015: 10; Jensen, Hougaard and Levisen 2019: 2). In all those genres, interjections feature abundantly, and their usage is crucial for the transmission of a message and ultimately for successful communication. Given this, drama plays, emails, WhatsApp messages, and comic strips can all be regarded as particularly suitable for the study of interjections and their behaviors. They offer rich and easily searchable corpora in which the grammatical profile of the category of interjections can be examined holistically, in both qualitative and quantitative terms. Such corpora are especially useful when examining the syntactic properties of interjections (Ameka 1992, 2006; Nübling 2004; Ameka and Wilkins 2006; Stange and Nübling 2014; Stange 2016).

The present paper aims to advance the study of interjections in isiXhosa by examining the syntactic behavior of the interjectional category from both a qualitative and quantitative perspective, as attested in one of the written-language genres where interjections are particularly abundant - comic strips. This research will be conducted within a prototype-driven approach to interjections (Ameka 1992, 2006; Nübling 2004; Ameka and Wilkins 2006; Stange and Nübling 2014; Stange 2016) and will answer the following research question: To what degree do interjections, found in the comic genre in isiXhosa, comply with syntactic features postulated for an interjectional prototype in scholarly literature - in particular, its syntactic extra-systematicity?

To achieve its objective, the article will be divided into four parts. In the next section (Section 2 ), we will introduce the framework underlying our research and the method with which the empirical corpus study was conducted. In Section 3, we will describe the behavioral profile of Xhosa interjections, emerging from our database. In Section 4, this profile will be evaluated within the adopted framework and the answer to the research question will be provided. Lastly, in Section 4, conclusions will be drawn.

\footnotetext{
${ }^{2}$ For a more comprehensive presentation of research on interjections in isiXhosa and Nguni scholarship, consult Andrason and Dlali (forthcoming).
} 


\section{Methodology: theoretical framework and method}

As indicated by its name, the fundamental concept in a prototype-driven approach to interjections is the prototype. The prototype of an interjection has been proposed in light of the features regularly exhibited by interjections across languages, as well as those features' saliency, i.e. the most conspicuous differentiation from other word classes (Ameka 1992, 2006; Nübling 2004; Ameka and Wilkins 2006; Stange and Nübling 2014; Stange 2016).

Overall, as far as syntax is concerned, the interjectional prototype is viewed as extra-systematic - it does not partake, or partakes with difficulty, in the syntactic system of a language (Stange 2016: 47-48). This general extra-systematicity of the interjectional prototype is cumulative, drawing on four more specific - equally extra-systematic - properties. First, contrary to many other word classes, interjections can be holophrastic - they may themselves form independent, complete, and self-contained utterances (Ameka 1992: 107-108, 2006: 743-745; Nübling 2004: 20, 30; Ameka and Wilkins 2006: 2; Velupillai 2012: 149-150; Stange and Nübling 2014: 19821983; Stange 2016: 20, 48). Second, when not used holophrastically, interjections fail to be integrated into the grammatical structure of a sentence, clause, or phrase (Ameka 1992: 112, 118, 2006: 745; Stange 2016: 14, 20, 47-48). They do not constitute the sentence's structural components, nor do they function as parts of broadly understood constructions - or conventional form-function pairing characterized by varying complexity, abstraction, and schematicity (Goldberg 1995, 2006, 2013; Fried and Östman 2004). Overall, they do not enter into grammatical relationships with other words (Ameka 1992: 112, 2006: 743-744; Stange and Nübling 2014: 1985). Third, interjections tend to appear in external positions, either utteranceinitial or utterance-final (Drescher 1997; Nübling 2001: 25, 2004: 31; Ameka and Wilkins 2006: 4; Nordgren 2015: 44). Fourth, they are separated from the remaining parts of the utterance (or sentence) by pause(s) and contouring, thus forming distinct intonation units (Ameka 1992: 108, 2006: 745; Stange and Nübling 2014: 1982; Nordgren 2015: 38, 45).

Even though the prototype of an interjection is a central concept in our approach, it cannot be equaled with the interjectional category itself. As defended by cognitive linguistics, the prototype structures the category but neither encapsulates nor represents it exhaustively (Croft 2003; Evans and Green 2006; Janda 2015). Crucially, instantiations of a category attested across languages may exhibit varying degrees of compliance with the prototype, being canonical (where more features are met) or non-canonical (where fewer features are met). The category envisaged in its totality is itself represented as a radial network of members that emanate from the center (canonical members) to the periphery (non-canonical members). The center is exemplified by the prototype, while at the periphery, the category overlaps with other categorial networks. Although both canonical and non-canonical members belong to the same category their membership status is uneven. As a result, categories become gradient phenomena, and their borders are viewed as fuzzy. ${ }^{3}$

Given the gradient nature of an interjectional network, language-specific interjections need not comply with the syntactic extra-systematicity associated with the prototype; or they may only do so to a certain extent. Indeed, most syntactic properties viewed as inherent to the interjectional prototype are violated across languages, with greater or lesser regularity.

\footnotetext{
${ }^{3}$ The approach referred to as 'canonical typology' developed by Corbett $(2005,2010$; see also Brown, Chumakina, and Corbett 2013) exhibits a strong similarity with the prototype-based approach to categorization that has been used extensively in cognitive linguistics for the past few decades.
} 
Interjections may be integrated into sentence structure and can form constructions. For instance, they are linked to vocatives through parataxis (Ameka and Wilkins 2006: 6) and appear in chains, yielding complex interjectional collocations and combinations (Nübling 2001: 25, 2004: 31; Ameka and Wilkins 2006: 4; Norrick 2009). Interjections may be tied to determined valency patterns, necessitating the presence of overt arguments (Ameka and Wilkins 2006: 7). Interjections may appear sentence-internally or even clause-internally. The phonological separation of interjections from the remaining parts of an utterance (or sentence) may be minimal with no pause or extra-sentential contour being present (Ameka and Wilkins 2006: 6; Nordgren 2015: 45). In extreme instances, interjections can be clitisized to other lexemes, thus forming a single prosodic word (Ameka and Wilkins 2006: 6).

Given the syntactic features associated with the prototype of interjections, and their violations, the method adopted in the empirical research on which this paper draws is the following: for each interjectional token, we study the properties that could reveal the extent of compliance or defiance of the syntactic prototype.

We primarily analyze whether each interjectional token constitutes an independent utterance or whether it is dependent - forming part of a larger utterance. ${ }^{4}$ In the former case, we examine whether it is isolated constituting a unique utterance in a given turn, or whether it appears as an initial, internal, or final utterance in a sequence of utterances in a turn. In the latter case - i.e. if an interjection constitutes a part of an utterance, we study: its prosodic relationship to the adjacent elements indicated by the various punctuation signs (comma, ellipsis, apostrophe) or their absence (juxtaposition); the lexical class of the adjacent element(s) (e.g. whether it is a noun (vocative or non-vocative), pronoun, verb, adverb, connective, or clitic particle); and, as previously, the position of the interjectional lexeme (i.e. initial, final, or internal). Additionally, we have examined whether an interjectional component - be it independent or dependent appears singly (one interjection is used); whether it is replicated (two, three, or more identical interjections are used); or whether it is used in combination with another interjection forming a chain (two or more different interjections are used). At the end of our empirical study, we compile a searchable multi-parameter database consisting of 1849 tokens.

In accordance with the prototype-driven approach, all semantic types of interjections irrespective of the degree of their interjectionality (Nübling 2004; Stange and Nübling 2014; Stange 2016: 17-18) have been included in our database and research, i.e.: (a) expressive (emotive and cognitive) interjections, which encode the emotional, sensorial, and mental states of the speaker (e.g. $o$, yho, or $a w u$ used to indicate surprise, anger, or fear); (b) conative interjections, which express wishes, convey commands, and function as attention getters (e.g. $s h h(h)$ and sssshhh to request silence); and (c) phatic interjections, which specify the attitude of the speaker towards the conversation and discourse (by initiating, sustaining, or terminating communication) and convey gratitude (enkosi), apology (uxolo), and salutations during welcoming (hey $(i)$, molo, bhota(ni)) or leave-taking (sala(ni) kakuhle). ${ }^{5}$ Similarly, we have

\footnotetext{
${ }^{4}$ The determination of utterance boundaries was based on topographic properties. The punctuation marks such as period (.), exclamation mark (!), and interrogation mark (?) were understood as indicators of the utterance boundary. In contrast, the comma (,) and ellipsis (...) were viewed as separating parts of a single utterance. In our empirical study and the subsequent discussion, we focus on utterances as syntactic units of analysis rather than as sentences.

${ }^{5}$ For a detailed semantic analysis of interjections consult Wierzbicka (1991, 1992), Ameka $(1992,2006)$, Nübling (2001), Ameka and Wilkins (2006), Stange and Nübling (2014), and Stange (2016).
} 
included in our database both primary (e.g. oh and $y h u)$ and secondary interjections (e.g. $N k o s(i$ y) am). ${ }^{6}$ Overall, all interjectional lexemes present in our database feature in the comprehensive set of interjections that has been compiled by Andrason and Dlali (forthcoming). ${ }^{7}$

The corpus from which the tokens composing our database have been extracted comprises the complete selections of half-a-page or one-page comic strips that were published monthly - with some interruptions - in the magazine Bona between 1981 and 2009. This selection includes four types of comics of distinct authorship, publication date, and overall length: Abafana written by Sydney Chama and published between 1981-1998 (190 comics); MaMgobhozi \& Mpintshi written by Wilson Mgobhozi and published in 1999 (5 comics); Dennis the Goat written by X. Shezi and Wilson Mgobhozi and published in 2000 (4 comics); and Majimbos written by Themba Siwela and published between 2002 and 2009 (47 comics). In total, 246 comics have been reviewed.

\section{Evidence}

Interjections constitute a highly prevalent feature of the comics analyzed for the purpose of this study. As mentioned above, there are 1849 interjections in the entire corpus, which gives an average of 7,5 interjections per single comic - whose length, as explained, oscillates between half a page or one page.

Although not all frames contain interjections, most of them do. In extreme cases, a single frame comprises more than ten interjectional items. In various frames, interjections constitute the main bulk of the utterances employed (1) or are the only words used (2). Frames that contain interjections as their unique elements may be monologic (they reproduce speech of only one person (3)) or dialogic (two or more speakers intervene (2 and 4)). Overall, interjections are exploited more commonly for dialogic (5 and 6) than monologic purposes (3). ${ }^{8}$

$\begin{array}{ll}\text { A: } & \text { Ndiyabona na nonke le banana } \\ \text { B: } & \text { Ya? } \\ \text { C: } & \text { Ewe? } \\ \text { D: } & \text { Hmm? }(1983 / 05) \\ \text { A: } & \text { Yho } \\ \text { B: } & \text { Yho } \\ \text { C: } & \text { Hum?? } \\ \text { D: } & \text { Yho } \\ \text { E: } & \text { Yhey } \\ \text { F: } & \text { Yho! } \\ \text { G: } & \text { Yhey }(1983 / 06)\end{array}$

$\begin{array}{ll}\text { A: } & \text { Awu! }(1989 / 11) \\ \text { A: } & \text { Maa! } \\ \text { B: } & \text { Yho! } \\ \text { C: } & \text { Awhu! } \\ \text { D: } & \text { Hayi! } \\ \text { E: } & \text { He? }(1984 / 04) \\ \text { A: } & \text { Yhi?? } \\ \text { B: } & \text { Molo, polisa }(1992 / 06) \\ \text { A: } & \text { Heyi, usebenzile } \\ \text { B: } & \text { Ewe, ewe }(1994 / 03)\end{array}$

\footnotetext{
${ }^{6}$ Regarding the distinction between primary and secondary interjections consult Ameka (1992: 111, 2006: 744), Norrick (2009), Stange and Nübling (2014: 1982-1983), Meinard (2015), and Stange (2016: 9, 19).

${ }^{7}$ This set was compiled by reviewing all isiXhosa dictionaries and grammars and by conducting original field work.

${ }^{8}$ The relevant interjections will be marked in bold throughout the article. Each example will be accompanied by a reference indicating the year and the months of publication. The capital letters A, B, C ... used in some examples stand for different speakers/characters intervening in a story. It should be noted that we will not translate the interjectional items as the equivalence between most isiXhosa interjections and their English rendering is elusive. Moreover, since our study is concerned with syntax, the exact meaning of the interjections is less relevant.
} 
Mostly, interjections (more than 66\%) are used as independent, fully fledged, and selfcontained utterances. ${ }^{9}$ Such interjectional utterances do not constitute elliptical or shortened versions of longer expressions. In a majority of cases, an independent interjection appears as the only utterance in a turn $(7,8,9) .{ }^{10} \mathrm{We}$ will refer to that position as isolated. To be exact, $74 \%$ of the independent interjections are isolated, which equals nearly $49 \%$ of all the tokens.
A: $\quad$ Mamela,...nantsi into ezisa kuyenza
B: Heke!! (1982/12)
A: Umhla wakhe wokuzalwa ngowekrisimesi.
B: Huh? (1996/04)

$\begin{array}{ll}\text { A: } & \text { Sisilingi sakho? } \\ \text { B: } & \text { Hayii } \\ \text { C: } & \text { Amabhastile akho? } \\ \text { B: } & \text { E-e-na } \\ \text { D: } & \text { Ukuwa ngendololwane? } \\ \text { B: } & \text { Eaayi. } \\ \text { E: } & \text { Imitya yezihlangu ezitsha? } \\ \text { B: } & \text { Hai maan. }(1996 / 08)\end{array}$

A smaller part of independent interjections, amounting to $26 \%$, are not isolated but appear adjacent to other utterances in a turn (10-13). In nearly $70 \%$ of such cases, a non-isolated independent interjection occupies an initial position, featuring at the beginning of a turn (10 and 11). A final position is significantly less common being attested in only $16 \%$ (12). An internal position is the least frequent $-14 \%$ of the non-isolated independent interjections are placed between two utterances (13).

Kwaye kunjalonje namhlanje
andinikezeli!! Nakanye! Nokuba
sekutheni!(1984/01)

Independent interjections that are not isolated tend to be separated from the adjacent utterances by the exclamation mark (see (10), (11), and (13) above). Much less commonly, the separation is achieved by an interrogation mark (14). Exceptionally, and in general only when used in a final position, a non-isolated independent interjection is separated from the other utterances by a full stop (see (12) above).
Hi? Heyi ntwana ungakhe undichazele eyona nto kanye uyenzayo?? (1984/09)

Owu? Khanindiculele ke (1983/11)

Even though independent interjections predominate, the use of interjections as parts of utterances is not exceptional. This type of usage is found in $34 \%$ of all the cases. In such instances - which will be referred to as dependent - an interjection is not the only component of an utterance. Rather, it forms that utterance together with other words: verbs, nouns, pronouns, adverbs, connectives, particles, etc. As was the case with independent interjections, dependent interjections typically occupy an utterance-initial position. Specifically, $93 \%$ of dependent interjections are found at the beginning of an utterance (16 and 17). In contrast, the placement of dependent interjections in an utterance-final position is less common, amounting to $4 \%$ (18 and 19). Dependent interjections that occupy an internal position, being thus

\footnotetext{
${ }^{9}$ This also includes chains of interjections.

${ }^{10}$ Of course, isolated interjections may themselves constitute part of longer dialogues (see especially example 9).
} 
intercalated between other components of the utterance, are even rarer. They constitute $3 \%$ of all dependent uses. In some cases, a single utterance may host both initial and final interjections (20). ${ }^{11}$

(16) Shhh, akukho mntu kufutshane apha? (1982/07)
Awu akasemhle torho (1984/06)

Njani maan? (1989/09)

Heyi Ntwana vuka maan! (1988/02) mnumzana phoyisa (1985/04)

A considerable number of utterance-initial dependent interjections is followed by a vocative noun (21 and 22). In isiXhosa, vocative nouns lack pre-prefixes, contrary to non-vocative forms used in affirmative as well as in certain types of negative constructions. Compare the vocative noun ntwana '(boy) child!' in (21) ${ }^{12}$ with its non-vocative form umntwana; or the proper name Sticks used vocatively in (22) with its non-vocative variant uSticks. The presence of an utterance-initial interjection before $2^{\text {nd }}$ person pronouns - which allow for the same vocative reading (see nina 'you (pl.)' in (23)) - is also attested, being nevertheless less common than is the case of vocative nouns.

(21) Heyi ntwana ungakhe undichazele eyona nto kanye uyenzayo $(1984 / 09)$
(22) Heyi Sticks, yintoni embi (1981/08)

(23) Heyi nina! (1984/10)

Utterance-initial interjections may also be found before non-vocative (pro)nominal forms such as pre-prefixed nouns $(i-R-20$ '(the) 20 rand' in (24)) or pronouns other than the those referring to the $2^{\text {nd }}$ person singular or plural ( $m n a$ ' $I$ ' in (25)). They may also be followed by verbs (ndiyaqonda 'I understand' in (26)), particles (ke in (27) and bo in (28)), adverbs (see 61 below), and other categories, e.g. copulatives (ngabafanas 'it is the young men (the Bafanas) again' in (29)), locative demonstrative copulatives (nantsi in (30)), ideophones (nqo 'straight' in (31)), and connectives (kodwa 'but, however' in (32)). As far as verbal inflectional categories are concerned, no restrictions are observed, for instance interjections are used with the perfect, the present, or the future tense.

Tyhini, i-R-20 yonke!! (1984/07)

Ewe, mna (1981/12)

$\boldsymbol{O}$, ndiyaqonda ke ngoku (1983/11)

Ngxatsho ke, ngoku ndiza kuthenga

laa ngxowa inkulu yetyuwa $(1982 / 11)$

Similarly, utterance-final interjections accompany a variety of lexical classes such as: nouns, either vocative (mama 'mom' in (33)) or non-vocative (indiri 'brain' in (34)), ${ }^{13}$ verbs (yonakele 'it is broken' in (35) and ndicela 'I ask' in (36)), or adverbs (see example (19) above), as well as more complex constructions, e.g. a prepositional phrase with a suffix pronoun $($ ngokwa $(\mathrm{m})$ '(by) myself' in (37)).

\footnotetext{
${ }^{11}$ From a semantic perspective, phatic interjections constitute the majority of dependent interjections. Even though considerably less common, the remaining semantic types may also function as dependent interjections.

12 The form ntwana is a colloquial contraction of mntwana.

13 This word is used in a peri-urban variety of isiXhosa and Tsotsitaal.
}

O, ngabafanas kwakhona (1983/11)

Heke, nantsi (1993/11)

Kulunge nqo! (1984/08)

(32) Ewe, kodwa ke zonke ezo zimuncu muncu zokutya neziselo ziya kufakwa isiyobisi ngobuchule (1985/04) 
Mama yooo!! (1996/08)

Uyayispanis' indiri heh? (2002: 10)

Kulula ukuthi iwotshi yam yonakele, ngxee! (1995/03)
Ndicela uxolo $(1983 / 02)$

Ndibaxelele ngokwa(m) yhoo hoo

hoo wham! (1985/04)

Dependent interjections are never integrated into the syntactic structure of the adjacent clause(s) with which they form an utterance. That is, they are not projected by the clause's predicate, nor do they function as adjuncts. They also fail to modify or complement the structural components of the clause, whether arguments or adjuncts (see examples 16-37 above).

The phonological relationship between interjections and the adjacent elements can only be inferred indirectly through punctuation used in writing. Dependent interjections (e.g., utteranceinitial (38) and utterance-final (39)) are separated from the remaining parts of the utterance by a comma in $37 \%$ of the possible cases. This overtly indicates the phonological disjunction of the interjection.

Nkos' am, andazi (1992/01)

Niyahleka, hi? (1985/05)

However, interjections may also be juxtaposed to the adjacent elements without any punctuation marks being used (40-43). This notation suggests that the interjection is phonologically conjunctive to the rest of a hosting utterance, or that a potential separation between the interjection and its utterance is minimal. ${ }^{14}$ The use of juxtaposition is overall slightly more common (55\%) than the presence of any overt orthographic "separatrix". It is attested with utterance-initial (40-42), as well as utterance-final interjections (43).

(40) OK hlekani nim'apho nithanda khona (1988/10)

(41) [...] Yheyi yima! (1991/11)

(42) Eyi Sticksie, uyazi kwenzekeni $(1992 / 09)$
(43) Ukuze ke nithi xa sele nitye nonke, nasela zemka, kuyakuba lula kakhulu ukunithatha ndimke nani nonke ha! (1985/04)

Juxtaposition is particularly common in cases where the interjection precedes a vocative noun, e.g. ntwana '(boy) child!' (44) and Bombie (45), or the $2^{\text {nd }}$ person pronouns, e.g. wena 'you' (46) (see also examples 37, 38). Indeed, an interjection and a vocative (whether noun or pronoun) are almost never separated by a comma or ellipsis (see also $(21,22,23)$ ). However, a comma typically separates the sequence composed of an interjection and a vocative (or $2^{\text {nd }}$ person pronoun) from the remaining part of the utterance (44-45) (see also (22) above). Juxtaposition is even more regular when the interjection is followed by a particle (47-48). That is, the interjection and the particle are never separated by a comma or ellipsis (see also (27-28) above). Other lexical classes may also appear without punctuation signs that would overtly separate them from interjections, even though their orthographic separation is more typical. Those lexical classes are non-vocative nouns and pronouns (e.g. mna 'I' in (49)), verbs (e.g. ayaphukangaka 'it is not broken' in (50) and ukhabe 'you've kicked' in (51)), as well as ideophones (see example 31, above).

\footnotetext{
${ }^{14}$ That is, it is irrelevant to the extent that it is not overtly indicated in writing.
} 
(44) Yee ntwana, khawuze nenoteboook eofisini yam! (1993/5)

(45) Wee Bombie, kanene unamhlanje, unamhlanje? (1995/05)

(46) Yheyi wena! (1993/10)

(47) Hayi ke ndilufumene ngoku ukuba luhlobo luni na lomdyarho ebezilubaleka (1982/09)
(48) Awu ke? (1985/12)

(49) Ewe nam ndibabonile kunjalo nje! $(1983 / 11)$

(50) Hayi ayaphukanga (1988/06)

(51) Kowu ukhabe inzwakazi! (1985/03)

Juxtaposition is also a common feature in cases where two different interjections are accumulated. Although the initial interjection in such chains is often separated from the subsequent one by a comma, the latter interjection tends to be linked to the remaining parts of the utterance through juxtaposition (52-54):

(52) Oo, hayi ke xa kunjalo kubi $(1992 / 09)$
(53) Kowu, hayi niziiexpress, bafana $(1993 / 07)$

(54) Awu, bhota ntwana! (1984/07)

Much less commonly (8\%), a dependent interjection and the adjacent part of the utterance whether the following (55-57) or the preceding one (58-59) - are linked via ellipsis. The use of ellipsis in writing suggests a great extent of phonological disjunction - significantly larger than was the case with a comma. The presence of ellipsis after utterance-initial interjections is more common than its use in front of utterance-final interjections. Ellipsis is also used to separate utterance-internal interjections from the left part of the utterance (60).

$$
\text { E...akumangalisi (1992/09) }
$$

Ehe...iphi impazamo kuloo nto? (1987/06)

Ssshh...naba kwakhona (1990/03)
Ndiza ku...heyi?! (1983/03)

Ndizawu...heyi?! (1991/02)

Hayi ke, ndobuya ndikubone...heyi nqanda!! (1988/06)

Exceptionally, dependent interjections and the adjacent components of an utterance are linked by means of an apostrophe (61-63). In such cases, the last vowel of an interjection is apocoped (see molweni $>$ molwen' in (61) and hayi > hay' in (62-63)). While ellipsis indicates a great degree of disjunction, the overt use of an apostrophe demonstrates the absence of phonological separation between the elements involved:

(61) Molwen'apho, manene! (1987/02)

(62) Hay'ungakhathazeki wena, sesikwazi thina (1991/07)
(63) Hay'ke sibulela kakhulu mnumzana phoyisa. (1985/04)

In general, the vast majority of interjections (73\%) are singletons. That is, they are used "monolexemically" - only one interjection is present (64-69). Interjectional singletons may function both as independent utterances (64-67) and as parts of utterances (68-69). They are also found in all positions. For instance, mono-lexemic independent interjections appear in an initial (64), final (65-66), and internal (see example (13) above) position, also allowing for isolated uses (67). Similarly, mono-lexemic dependent interjections are found utterance-initially (68), finally (69), and internally (see example (60) above). 
(64) Yho! Ngumnumzana uphoyisa! $(1985 / 04)$

(65) Masiyiyeke iphumle njengezinye. Amen! (1982/07)

(66) Ndehlelwa yintoni? Ndehlelwa yintoni? Mayee-e-e (1988/03)
A: Kanti kwenzeke ntoni polisa?

B: $\boldsymbol{N} \boldsymbol{x} !(1988 / 01)$

Heyi, intle le nto (1988/06)

Ndicela uxolo (1983/02)

Although mono-lexemic interjections prevail, complex interjections are not uncommon. They are found in nearly $27 \%$ of all the cases. The main bulk of complex interjections involve the replication of one basic interjectional lexeme. Most often, an interjection is repeated twice, thus yielding cases of reduplication (70-74). The reduplicated interjections may belong to a larger utterance (70-71). They may also constitute the only elements of an utterance (72). Alternatively, they may, each, form an independent utterance, being separated - from one other as well as from the other utterances in a turn - by an exclamation sign (73-74).

Heyi, heyi, manene, siphantse salibala into ebaluleke kakhulu efanele abafundi bebona $(1981 / 12)$
Heyi heeeyi!! (1985/03)

Hmm! Hmm! (1983/03)

Hanewu! Hanewu! Asilithandi ibala legazi!! (1983/05)

Much less frequently, an interjectional lexeme is replicated three times (75-77). Triplicated interjections may be located within a larger utterance or they may constitute the only elements of an utterance (75). Interjectional triplets may also function as three consecutive utterances, regularly separated by exclamation signs (76-77). Exceptionally - and in the analyzed corpus, only as part of larger multi-interjectional complexes - interjections may be repeated four or five times (see examples (86) and (88) further below).

(75) Ha ha ha! (1984/05)

(76) Yho! Yho! Yho! (1982/12)
(77) Yo! Yo! Yo! Udubule ubra [S]'qwayi, isigantsontso (1991/02)

Apart from replications, complex interjections may also surface as sequences of different interjectional lexemes. By far the most common combinations are series composed of two interjections, schematically represented as $i_{1}+i_{2}$ (78-82). ${ }^{15}$ Such bi-member sequences may constitute parts of larger utterances (78-80). Alternatively, they may form, all together, their own utterance (81). They can also constitute two separate independent utterances (82).

Tyhini ewe, sive lukhulu ngani $(1984 / 06)$

Oo, hayi ke xa kunjalo kubi $(1992 / 09)$

Tyhini molo Bootzee, kunja[ni]? $(1992 / 11)$
(81) Owu Nkosi yam $(1982 / 11)^{16}$

(82) Owu! Nkosi yam. Bendiba ndiwuphephe kamnandi nje lo mbuzo $(1991 / 11)$

More elaborated sequences than those introduced above are also attested in the corpus. They are, however, significantly less frequent. A number of complex interjectional sequences draw

\footnotetext{
${ }^{15}$ The symbol $i$ stands for 'interjection' and the subscript indicates its order, e.g. $i_{1}$ is the first interjection in a series, $i_{2}$ is the second, and so on.

${ }^{16}$ Nkosi yam is a single, secondary interjection.
} 
on three different basic interjections, exhibiting the structure $i_{1}+i_{2}+i_{3}$ (83-84). Sometimes, one of the three interjections may be replicated yielding the pattern $i_{1}+i_{2}+i_{2}+i_{3}$ as found in (85). The replication of the interjectional components may involve more than one lexeme in a sequence, each being able to be repeated more than twice (86).

$$
\begin{aligned}
& \text { Oo, hayi wena ndiyiphiwe } \\
& (1992 / 12)
\end{aligned}
$$

Owu hay maan, ngoku ibhola ayisebenzi (1984/09)

Ndibaxelele ngokwa yhoo hoo hoo whaa! (1985/04)

Ha ha ha ha ho ho ho hee hee hee $(1991 / 05)$

Occasionally, one finds sequences composed of four, five, or six different interjections (88-89). Often, at least one of them is repeated twice, three times, or even four times:

\author{
Ha! Ha! Ha! Ho! Ho! Ho! Ha! \\ Hee! Hee! Hee! (1985/05)
}

Oh ha ha ha ho ho ho ho! Tee hee! $(1985 / 05)$

\title{
4. Discussion
}

The evidence presented in Section 3 demonstrates that interjections in isiXhosa often conform to the interjectional prototype as far as their syntax is concerned:

(a) Interjections tend to function holophrastically, forming independent, complete, and selfcontained utterances.

(b) Interjections frequently resist syntactic integration. This is evident for independent interjections and also often holds true for the interjections that form parts of utterances. Dependent interjections are never integrated into the structure of the adjacent clause with which they form an utterance. They do not constitute structural components of that clause, being, for instance, projected by its verb. They are neither governed by the verb's arguments and adjuncts, nor do they modify and complement the clause's structural elements. In various cases, dependent interjections do not enter into grammatical relationships with any words employed in the utterance, thus failing to yield broadly understood constructions.

(c) Interjections exhibit a considerable degree of linear peripherality. In non-isolated uses, whether as independent utterances or as parts of larger utterances, interjections overwhelmingly occupy peripheral positions, typically the initial one.

(d) Interjections are often separated topographically from the remaining parts of the sentence by a comma or (less commonly) ellipsis. This punctuation suggests a phonological disjunction of an interjection from the adjacent elements, and a likely interpretation of the interjectional segment as a separate prosodic unit. ${ }^{17}$

However, the above-mentioned compliance with the interjectional prototype is not absolute, and several violations are attested:

(a) Interjections often form parts of larger utterances.

\footnotetext{
${ }^{17}$ By definition, all the independent interjections, which constitute self-standing utterances, are phonologically separated from the other utterances or conversation turns.
} 
(b) Interjections are able to maintain syntactic relationships with grammatical elements at a phrasal and sentential level. On the one hand, interjections enter into constructions. Specifically, (i) interjections form phrases with vocative nouns and $2^{\text {nd }}$ person pronouns; (b) interjections fall under the scope of, or are restricted by, clitic particles; and (c) interjections yield interjectional chains, either by being replicated or by co-occurring with other interjections.

(c) Interjections - both independent and dependent - may sporadically occupy internal positions. They are either intercalated between two utterances or placed utteranceinternally.

(d) Interjections are often topographically joined to the remaining parts of an utterance. Overall, the use of juxtaposition is slightly more common than the use of all separatrices jointly. In rare instances, interjections can be linked to other lexemes by an apostrophe. The commonness of juxtaposition and the presence of an apostrophe-type linking suggest a high degree of phonological conjunction between interjections and the subsequent elements, allowing, in some cases, for the interpretation of these two segments as a single prosodic word.

The results of our empirical study demonstrate that the canonicity of Xhosa interjections is not uniform. On the one hand, interjections may exhibit a canonical profile. In such cases, they comply with the cross-linguistic interjectional prototype by being independent, non-integrated, linearly peripheral, and phonologically disjunctive. On the other hand, the canonicity of interjections may be more limited. Interjections can transgress prototypical features by being (more) dependent, integrated, linearly central, and phonologically conjunctive. Accordingly, the extra-systematicity of interjections fails to be uniform. Interjections oscillate between high levels of extra-systematicity (typical of canonical interjections) and low levels thereof (typical of non-canonical interjections). Consequently, rather than forming a homogeneous set, the category of interjections in isiXhosa is internally complex and diversified (cf. Nübling 2004: 11-16; Norrick 2009: 889), containing members of distinct canonicity and, thus, extrasystematicity degrees. The radical generalizations regarding the syntactic oddity of interjections occasionally found in isiXhosa scholarship (Louw and Jubase 1963: 255; Schonstein Pinnock 1994: 196; Oosthuisen 2016: 357) should therefore be regarded with more caution.

Additionally, the present research confirms certain phenomena and tendencies identified previously in scholarship, either by nuancing them further or by providing their robust empirical foundation. First, our study corroborates the view of the systemic relevance of interjections in isiXhosa grammar. While the high type-frequency of the interjectional category has been established by Andrason and Dlali (forthcoming), who have identified nearly 350 fully grammaticalized and/or lexicalized interjections in isiXhosa, our corpus demonstrates similarly impressive token-frequency. ${ }^{18}$ At least in the comic genre, interjections are equally frequent as verbs and nouns - the most common lexemes in isiXhosa. In some comic strips, the occurrence of interjections even exceeds that of all the other lexical classes combined. Second, our research shows that violations of interjectional holophrasticity (i.e. instances where interjections are dependent) and non-constructionality (i.e. instances where interjections are used with vocatives and $2^{\text {nd }}$ person pronouns) are most commonly attested with conative and phatic interjections. This corroborates the less orthodox character of these two types of interjections if compared to

\footnotetext{
${ }^{18}$ Regarding the distinction between type and token frequency, consult Hopper and Traugott (2003).
} 
other interjections, especially the emotive ones (Nübling 2004: 17-19, 34-35; Ameka 2006: 743; Stange and Nübling 2014: 1982-1983; Stange 2016: 13, 17-19).

Overall, our study corroborates the validity of a prototype approach to interjections (Ameka 1992, 2006; Nübling 2004; Ameka and Wilkins 2006; Stange and Nübling 2014; Stange 2016). On the one hand, we agree that the interjectional prototype is essentially extra-systematic from a syntactic perspective, as proposed in scholarly literature. On the other hand, we observe a number of violations, which are, again, fully congruent with those identified previously in scholarship. In harmony with the prototype approach, interjections exhibiting such violations should not be denied categorial membership. Rather, they should be interpreted as occupying a peripheral position in the radial network of the interjectional category.

\section{Conclusion}

This paper offered an empirical, corpus-driven examination of the syntactic properties of interjections in isiXhosa - the first attempt of this in isiXhosa scholarship. The analysis demonstrates that isiXhosa interjections often comply with the prototype of interjections postulated in typological literature, thus exhibiting an extra-systematic profile. However, their canonicity - and thus extra-systematicity - is not universal. In various instances, interjections exhibit less canonical properties, being inversely more systematic from a syntactic perspective. As a result, the category of interjections in isiXhosa contains members of varying degrees of canonicity and extra-systematicity. Overall, interjections appear as one of the most frequent components of the discourses analyzed in this article, which suggests their crucial importance for communication generally, and in isiXhosa specifically.

\section{Examples cited}

(1-33, 35-88) Chama, S. 1981-1998. Abafana. Bona.

(34) Siwela, T. 2002. Majimbos. Bona.

\section{References}

Ameka, F. 1992. Interjections: the universal yet neglected part of speech. Journal of Pragmatics 18: 101-118. https://doi.org/10.1016/0378-2166(92)90048-g

Ameka, F. 2006. Interjections. In K. Brown (ed.) Encyclopedia of Language and Linguistics. $2^{\text {nd }}$ edition. Oxford: Elsevier. pp. 743-746. https://doi.org/10.1016/b0-08-044854-2/00396-5

Ameka, F. and D. Wilkins. 2006. Interjections. In J-O. Östman and J. Verschueren (eds.) Handbook of Pragmatics. Amsterdam: John Benjamins. pp. 1-19.

Andrason, A. and M. Dlali. (forthcoming). The (crucial yet neglected) category of interjections in Xhosa. STUF - Language Typology and Universals 73. 
Bednarczyk, M. 2015. Morphosyntactic features of interjections in German comic books. Białostockie Archiwum Językowe 15: 9-19. https://doi.org/10.15290/baj.2015.15.01

Bennie, W.G. 1953. A Grammar of Xhosa for the Xhosa-Speaking. Lovedale: Lovedale Press.

Brown, D., M. Chumakina and G.G. Corbett (eds.). 2013. Canonical Morphology and Syntax. Oxford: Oxford University Press. https://doi.org/10.1017/s0022226714000097

Bryant, A. 2007. Xhosa for Second-Language Learners: Senior School and Beyond. Cape Town: Alexandra Bryant Publisher.

Corbett, G.G. 2005. The canonical approach in typology. In Z. Frajzyngier, A. Hodges and D. Rood (eds.) Linguistic Diversity and Language Theories. Amsterdam: John Benjamins. pp. 2549. https://doi.org/10.1075/slcs.72.03cor

Corbett, G.G. 2010. Canonical derivational morphology. Word Structure 3(2): 141-155. https://doi.org/10.3366/word.2010.0002

Croft, W. 2003. Typology and Universals. Cambridge: Cambridge University Press.

De la Cruz Cabanillas, I. and C. Tejedor Martínez. 2009. La influencia de las formas inarticuladas, interjecciones y onomatopeyas inglesas en los tebeos españoles. Revista de Lingüística y Lenguas Aplicadas 4: 47-58. https://doi.org/10.4995/rlyla.2009.734

Drescher, M. 1997. French interjections and their use in discourse: ah dis donc les vieux souvenirs. In S. Niemeier and R. Dirven (eds.) The Language of Emotions: Conceptualization, Expression, and Theoretical Foundation. Amsterdam: John Benjamins. pp. 233-246. https://doi.org/10.1075/z.85.18dre

Du Plessis, J.A. 1978. IsiXhosa 4. Goodwood: Oudiovista.

Evans, V. and M. Green. 2006. Cognitive Linguistics: An Introduction. Edinburgh: Edinburgh University Press.

Fernández Cuesta, J. 1990. La interjección en inglés. Estudio lingüístico y literario con especial referencia al español. $\mathrm{PhD}$ dissertation, Universidad de Salamanca.

Forster, I., S. Borgwaldt and M. Neef. 2012. Form follows function: Interjections and onomatopoetica in comics. Writing Systems Research 4(2): 122-139. https://doi.org/10.1080/17586801.2012.751348

Frehner, C. 2008. Email, SMS, MMS: The Linguistic Creativity of Asynchronous Discourse in the New Media Age. Bern: Peter Lang. https://doi.org/10.1017/s0047404510000813

Fried, M. and J-O. Östman. 2004. Construction Grammar: A Thumbnail Sketch. In M. Fried and J-O. Östman (eds.) Construction Grammar in a Cross-Language Perspective. Amsterdam: John Benjamins. pp. 11-86. https://doi.org/10.1075/cal.2.02fri 
Goldberg, A. 1995. Constructions: A Construction Grammar Approach to Argument Structure. Chicago: University of Chicago Press.

Goldberg, A. 2006. Constructions at Work: The Nature of Generalization in Language. Oxford: Oxford University Press.

Goldberg, A. 2013. Constructionist Approaches. In T. Hoffmann and G. Trousdale (eds.) The Oxford Handbook of Construction Grammar. Oxford: Oxford University Press. pp. 15-31. https://doi.org/10.1093/oxfordhb/9780195396683.013.0002

Janda, L. 2015. Cognitive linguistics in the year 2015. Cognitive Semantics 1: 131-154.

Jensen, E.S., Hougaard, T.T and C. Levisen. 2019. Interjections in Scandinavia and beyond: Traditions and innovations. Scandinavian Studies in Language 10(1): 1-6.

Jordan, A.C. 1966. A Practical Course in Xhosa. Johannesburg: Longmans.

Kirsch, B., S. Skorge and S. Magona. 1999. Xhosa. London: Teach Yourself Books.

Louw, J.A. and J.B. Jubase. 1963. Handboek van Xhosa. Johannesburg: Bonapers Beperk.

Mncube, F.S.M. 1957. Xhosa Manual. Johannesburg: Juta.

Nordgren, L. 2015. Greek Interjections. Berlin: De Gruyter Mouton.

Norrick, N. 2009. Interjections as pragmatic markers. Journal of Pragmatics 41: 866-891. https://doi.org/10.1016/j.pragma.2008.08.005

Nübling, D. 2001. Von oh mein Jesus! zu oje! - Der Interjektionalisierungspfad von der sekundären zur primären Interjektion. Deutsche Sprache 29(1): 20-45.

Nübling, D. 2004. Die prototypische Interjektion: Ein Definitionsvorschlag. Zeitschrift für Semiotik 26(1-2): 11-46.

Oosthuisen, J. 2016. The Grammar of isiXhosa. Stellenbosch: Sun Press.

Romero-Trillo, J. 2006. Discourse markers. In K. Brown (ed.) Encyclopedia of Language and Linguistics. $2^{\text {nd }}$ edition. Oxford: Elsevier: 639-641.

Schonstein Pinnock, P. 1994. Xhosa: A Cultural Grammar for Beginners. Cape Town: African Sun Press.

Stange, U. and D. Nübling. 2014. Interjections. In C. Müller, A. Cienki, E. Fricke, S. Ladewig, D. McNeill and S. Tessendorf (eds.) Body - Language - Communication. Berlin: De Gruyter Mouton. pp. 1982-1989. 
Stange, U. 2016. Emotive Interjections in British English. A Corpus-Based Study on Variation in Acquisition, Function and Usage. Amsterdam: John Benjamins. https://doi.org/10.1075/scl.75

Velupillai, V. 2012. An Introduction to Linguistic Typology. Amsterdam: John Benjamins.

Wierzbicka, A. 1991 [2003]. Cross-cultural Pragmatics: The Semantics of Human Interaction. $2^{\text {nd }}$ edition. Berlin: De Gruyter Mouton.

Wierzbicka, A. 1992. The semantics of interjections. Journal of Pragmatics 18: 159-192.

Zotwana, S.Z. and J. Wilson. 1991. Xhosa in Context: From Novice to Intermediate. Cape Town: Vlaeberg. 